\title{
Optimizing the Selective Precipitation of Iron to Produce Yellow Pigment from Acid Mine Drainage
}

Rodrigo de Almeida Silva ${ }^{1 *}$, Marina Paula Secco ${ }^{1}$, Richard Thomas Lermen ${ }^{1}$, Ivo André Homrich Schneider ${ }^{2}$, Gelsa Edith Navarro Hidalgo ${ }^{3}$, Carlos Hoffmann Sampaio ${ }^{4}$

${ }^{1}$ Master of Civil Engineering (PPGEC), Department of Civil Engineering, Polytechnic School, Meridional College (IMED), Passo Fundo, Rio Grande do Sul, 99070-220, Brazil; rodriogo.silva@imed.edu.br (R.A.S.); marina.secco@imed.edu.br (M.P.S.); richard.lermen@gmail.com (R.T.L.).

${ }^{2}$ Laboratory of Mineral and Environmental Technology (LTM), Post-Graduate Program in Mining, Metallurgical and Materials Engineering (PPGE3M), Department of Engineering, Federal University of Rio Grande do Sul (UFRGS), Porto Alegre, Rio Grande do Sul 90130-120, Brazil; ivo.andre@ufrgs.br (I.A.H.S.).

${ }^{3}$ Laboratory of Mineral Processing (LAPROM), Post-Graduate Program in Mining, Metallurgical and Materials Engineering (PPGE3M), Department of Engineering, Federal University of Rio Grande do Sul (UFRGS), Porto Alegre, Rio Grande do Sul 90130-120,Brazil; gelsaedith@ufrgs.br (G.E.N.H.)

${ }^{4}$ Professor Serra Húnter, Departament d'Enginyeria Minera, Industrial i TIC, Universitat Politècnica de Catalunya Barcelona Tech. Av. Bases de Manresa 61-63, Manresa, 08242 Barcelona, Spain; carlos.hoffmann@upc.edu (C.H.S.)

"Correspondence: rodrigo.silva@imed.edu.br; Tel.: +55 (54) 3045-6100

\begin{abstract}
Acid mine drainage (AMD) in the coal mining industry is recognized as one of the major sources of environmental damage. The active treatment of AMD involves adding alkaline reagents to wastewater so as to raise $\mathrm{pH}$ and to precipitate dissolved metals in the form of oxides/hydroxides. Studies have shown that yellow pigment (goethite) can
\end{abstract}


be produced from the iron present in AMD. However, the presence of other metals can prevent the formation of pigment. Therefore, this paper seeks to evaluate several processes for purifying iron sludge so as to obtain raw material that can be recovered from AMD and thereby obtain a good quality of yellow pigment. The experiments were carried out by causing precipitation with strong and weak bases and removing other metals from the sludge by washing and filtering the sludge or by centrifugation. The results show that the color, type and morphology of the compounds changed, depending on the number of contaminants, and that these factors are strongly dependent on the type of reagent and less dependent on the separation process and the repetition of washes.

Keywords: iron pigments, goethite, hematite, selective precipitation, acid mine drainage 


\section{Introduction}

The acid mine drainage (AMD), generated by the natural oxidation of mine waste containing mineral sulfides, has an adverse impact on the environment in many regions all over the world. To control and avoid AMD in mining activities, many types of treatment to reduce damage to the environment are used (Nordstrom et al., 2017). The active treatment of $A M D$ involves adding alkaline reagents to it so as to increase the $\mathrm{pH}$ and then to precipitate dissolved metals in the form of hydroxides. Although active treatment can provide effective remediation, its disadvantages are that the operational costs are high and there are problems related to disposing of the bulky sludge that is produced (Kontopoulos, 1998; Skousen et al., 1998; Skousen and Ziemkiewicz, 1995).

In Brazil, AMD is generated and treated at coal mining sites. The precipitation of metals involves adding sodium hydroxide or lime to AMD. The sludge that is then formed is removed in settling ponds, conventional settling tanks, lamellar tanks, and dissolved air flotation units (Silveira et al., 2009). Sludge typically contains $2-5 \%$ solids and high concentrations of iron and aluminum along with minor concentrations of manganese, zinc, and other metals (Marcello et al., 2008).

Studies have shown that industrial materials can be obtained by precipitating iron selectively from AMD. Some studies have already shown that the sludge obtained from AMD can be a source from which to produce coagulants (Finch et al., 1992; Menezes et al., 2009, 2010), adsorbents and catalysts (Flores et al., 2012), and magnetic particles such as magnetite and other ferrites (Silva et al., 2012; Wei et al., 2005). Recently, the pigments goethite and hematite were successfully obtained by selectively precipitating iron and this sludge has been used to make colored mortar (Silva et al., 2017).

To promote the selective precipitation of iron (III) which is present in the AMD as iron hydroxide, an alkaline agent must be added at $\mathrm{pH}$ of between 3.6 to 3.8. The aim of this study was to optimize the process for precipitating iron (III) selectively by assessing three variables (the reagent, the number of washes and the separation 
method). In this study, two alkaline agents with different neutralization powers and two processes for solid-liquid separation were used. The iron hydroxide obtained was used to produce goethite by the potassium hydroxide route (Cornell and Schwertmann, 2003). The yellow pigment obtained can be applied in formulations that give color to concrete, mortar or coating paint.

\section{Chemical reactions}

The conventional synthesis of goethite by means of the chemical precipitation of the iron in AMD includes the following steps: precipitate iron selectively, dissolve the iron; and crystallize goethite (Cornell and Schwertmann, 2003; Schneider, 1984;

Schwertmann and Murad, 1983; Schwertmann et al., 2004; Silva et al., 2017):

To precipitate iron selectively, prompt the hydrolysis of soluble iron by adding alkali so as to precipitate the metal as ferric hydroxide at $\mathrm{pH} 3.7 \pm 0.1$. This helps separate iron from other metals present in AMD. The process should be followed by successive washes with an aqueous solution at the same $\mathrm{pH}$ in order to remove the undesirable contaminants present in the interstitial water (Reaction 1):

$$
\mathrm{Fe}^{3+}{ }_{(\mathrm{aq})}+3 \mathrm{OH}_{(\mathrm{aq})}^{-} \rightarrow \mathrm{Fe}(\mathrm{OH})_{3(\mathrm{~s})}
$$

In order to dissolve iron, iron hydroxide should be dissolved in water by adding nitric acid to form a water complex called iron-hexa-aquo ion, as shown in Reaction 2 :

$$
\mathrm{Fe}(\mathrm{OH})_{3(\mathrm{~s})}+3 \mathrm{HNO}_{3(\mathrm{aq})} \rightarrow\left(\left[\mathrm{Fe}\left(\mathrm{H}_{2} \mathrm{O}\right)_{6}\right]^{3+}\right)_{(\mathrm{aq})}
$$

The goethite formation can be induced by alkaline conditions that precipitate a ferric solution (iron-hexa-aquo-ion), thereby producing a precipitate called ferrihydrite $\left(\mathrm{Fe}_{5} \mathrm{HO}_{8} .4 \mathrm{H}_{2} \mathrm{O}\right)$ when potassium hydroxide at $\mathrm{pH} 12.0$ is added, as shown in Reaction 3: 


$$
\left(\left[\mathrm{Fe}\left(\mathrm{H}_{2} \mathrm{O}\right)_{6}\right]^{3+}\right)_{(\mathrm{aq})}+\mathrm{KOH}_{(\mathrm{exc})} \rightarrow\left(\mathrm{Fe}_{5} \mathrm{HO}_{8} \cdot 4 \mathrm{H}_{2} \mathrm{O}\right)_{\mathrm{n}(\mathrm{s})}
$$

Under these conditions, the initially formed precipitate was dissolved and an ionic species $\left(\mathrm{Fe}(\mathrm{OH})_{4}{ }^{-}\right)$was released which later formed crystalline goethite by nucleation, thus beginning the process of growth of goethite $(\alpha-\mathrm{FeOOH})$, - see Reactions 4 and 5.

$$
\begin{aligned}
\left(\mathrm{Fe}_{5} \mathrm{HO}_{8} \cdot 4 \mathrm{H}_{2} \mathrm{O}\right)_{\mathrm{n}(\mathrm{s})} & \rightarrow\left[\mathrm{Fe}(\mathrm{OH})_{4}\right]_{(\mathrm{aq})} \\
{\left[\mathrm{Fe}(\mathrm{OH})_{4}\right]_{(\text {aqueous })} } & \rightarrow \alpha-\mathrm{FeOOH}_{(\mathrm{s})}
\end{aligned}
$$

\section{Materials and Methods}

The 4 steps followed to obtain the material and conduct the methods were as follows: prepare the sample; recover the iron and prepare a solution; synthesize and characterize yellow and red pigments; and design experiments. These are described in more detail in the following sections.

\subsection{Preparing the sample}

AMD was collected from the drainage channel of a coal tailings deposit in the north of Parana State (Brazil) and sealed in high-density polyethylene bottles. In the laboratory, the solids present in the samples were removed by filtration using

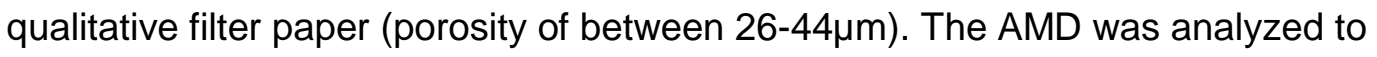
determine its $\mathrm{pH}$ and the percentage concentrations of dissolved metals (total Fe, $\mathrm{Al}$, Mn and $\mathrm{Zn}$ ) and sulfate, following the procedures described in the Standard Method for the Examination of Water and Wastewater (Eaton et al., 2005) 


\subsection{Recovering the iron and preparing a solution}

Iron was recovered by selective precipitation from $\mathrm{AMD}$ at $\mathrm{pH} 3.6 \pm 0.1$ by adding sodium hydroxide $(\mathrm{NaOH})$ or sodium bicarbonate $\left(\mathrm{NaHCO}_{3}\right)$ so as to precipitate the iron (III) as ferric hydroxide/oxyhydroxide. After adjusting the $\mathrm{pH}$, the sample was aerated for 24 hours with compressed air to oxidize $\mathrm{Fe}^{2+}$ to $\mathrm{Fe}^{3+}$. Then it was decanted and washed with distilled water, and finally it was filtered or centrifuged. Contact time of Fe-precipitate in the washing procedure was 24 hours.

\subsection{Synthesizing and characterizing the yellow and red pigments}

To produce goethite $(\alpha-\mathrm{FeOOH})$, the ferric precipitated sludge was dissolved with nitric acid which resulted in an iron-hexa-aqua-ion complex (Reaction 2). This solution was alkalized with potassium hydroxide and, then, the mixture was immediately diluted with water and the $\mathrm{pH}$ was adjusted to 12.0 , which changed the mixture to a red-orange color called ferrihydrite - see Reaction 3. The 36 samples were heated to $70^{\circ} \mathrm{C}$ for periods of sixty hours in order to crystallize the goethite (Reactions 4 and 5). After this reaction time, the supernatant was removed from the sample and the solid formed was dried, and kept in a polythene flask for chemical, colorimetric, morphological and mineralogical characterization.

\subsection{Design of the experiment}

An experimental design matrix with 12 assays was drawn up. Three specimens of each assay were prepared to reduce the sampling error and therefore, a total of 36 specimens was produced. The experimental design was based on a full factorial statistical method. The respective values are shown in Table 1.

Table 1

Experimental matrix of iron (III) precipitation.

\begin{tabular}{cccccc}
\hline Assays & Reagent & $\begin{array}{c}\text { Reagent } \\
\text { Amount }(\mathrm{g})\end{array}$ & $\begin{array}{c}\text { Separation } \\
\text { Method }\end{array}$ & $\begin{array}{c}\text { AMD } \\
\text { Amount }(\mathrm{L})\end{array}$ & $\begin{array}{c}\text { Number of } \\
\text { Washes }\end{array}$ \\
\hline 1 & $\mathrm{NaHCO}_{3}$ & 5.7 & Filtration & 1.0 & 0 \\
2 & $\mathrm{NaHCO}_{3}$ & 5.7 & Filtration & 1.0 & 1 \\
\hline
\end{tabular}




\begin{tabular}{ccccll}
\hline 3 & $\mathrm{NaHCO}_{3}$ & 5.7 & Filtration & 1.0 & 2 \\
4 & $\mathrm{NaHCO}_{3}$ & 5.7 & Centrifugation & 1.0 & 0 \\
5 & $\mathrm{NaHCO}_{3}$ & 5.7 & Centrifugation & 1.0 & 1 \\
6 & $\mathrm{NaHCO}_{3}$ & 5.7 & Centrifugation & 1.0 & 2 \\
7 & $\mathrm{NaOH}$ & 3.6 & Filtration & 1.0 & 0 \\
8 & $\mathrm{NaOH}$ & 3.6 & Filtration & 1.0 & 1 \\
9 & $\mathrm{NaOH}$ & 3.6 & Filtration & 1.0 & 2 \\
10 & $\mathrm{NaOH}$ & 3.6 & Centrifugation & 1.0 & 0 \\
11 & $\mathrm{NaOH}$ & 3.6 & Centrifugation & 1.0 & 1 \\
12 & $\mathrm{NaOH}$ & 3.6 & Centrifugation & 1.0 & 2 \\
\hline
\end{tabular}

An analysis of variance (ANOVA) was used to determine the influence of several factors on the output variables. Factors were significant for $p$-values equal to or lower than 0.05 (the critical value adopted), which indicates a confidence level equal or superior to $95 \%$ with respect to what is being stated. The percentage contribution of each factor was also determined.

\section{Results and Discussion}

The main elements in AMD are iron, aluminum, manganese, zinc and sulfate ion. The initial $\mathrm{pH}$ in $\mathrm{AMD}$ was 2.8 , when $\mathrm{pH}$ increased to $3.7 \pm 0.1$, the dissolved iron drops from around $2840 \mathrm{mg} / \mathrm{l}$ to about $500 \mathrm{mg} / \mathrm{l}$, indicating that, approximately, $82 \%$ of the iron was removed as iron hydroxide/oxyhydroxide, by $\mathrm{NaOH}$ and $\mathrm{NaHCO}_{3}$.

With regard to aluminum, the initial concentration was around $690 \mathrm{mg} / \mathrm{l}$, but when $\mathrm{NaOH}$ was used to cause precipitation, the concentration reduced to around 350 $\mathrm{mg} / \mathrm{l}$, which led to $61.4 \%$ of the aluminum being removed. When $\mathrm{NaHCO}_{3}$ was used, the aluminum concentration fell to $48.6 \mathrm{mg} / \mathrm{l}$, which showed that $94.2 \%$ of the aluminum had been removed.

The concentrations of zinc and manganese in AMD were around $63 \mathrm{mg} / \mathrm{L}$ and $270 \mathrm{mg} / \mathrm{L}$ respectively. However, when iron precipitation was carried out with $\mathrm{NaOH}$, zinc and manganese were found in sample (assay 9) with a value of around $0.1 \%$ each, but this was not found when $\mathrm{NaHCO}_{3}$ was added to cause the precipitation (assay 6). The sulfate concentration was $5860 \mathrm{mg} / \mathrm{L}$ which is its usual value in AMD due to sulfur oxidizing the pyrite content. 
The reagent is the most important parameter for removing aluminum from AMD (an influence of around 95\%). The difference in the amount of metal removed depending on whether $\mathrm{NaHCO}_{3}$ or $\mathrm{NaOH}$ is used is around $32 \%$. Sodium hydroxide is a strong base and sodium bicarbonate is a weak base. While of reagent is being added, a pH gradient occurs before the solution is totally equalized. These $\mathrm{pH}$ variations around the drop (for the present purpose, it is useful to consider the drop of base immersed in a solution), promote the precipitation of other metals present in AMD, mainly aluminum. The higher the local $\mathrm{pH}$, the more impurities there will be in the precipitate (Schneider, 1984; Silva, 2010; Stumm and Morgan, 2012).

Moreover, at pH 3.6, the concentration of other metals remained nearly unchanged or fell slightly, which ensured that the iron precipitated was of high purity. When the $\mathrm{pH}$ was adjusted to $\mathrm{pH} 7.0$, the water quality met the Brazilian Standards for Wastewater Discharge, (CONAMA, 2011), as shown by Silva et al. (2017).

Using the analysis of variance (ANOVA), presented in Table 2, it can be concluded, with $95 \%$ degree of certainty, that the reagent and separation method were the factors that had a significant influence on the removal of the aluminum concentration, but the reagent was the factor that had, by far, the greatest influence, its contribution being $95 \%$. The interaction of factors and the number of washes did not change the level of aluminum concentration.

\section{Table 2}

Analysis of Variance (ANOVA) for the aluminum concentration.

\begin{tabular}{ccccccc}
\hline Factor & $\begin{array}{c}\text { Sum of } \\
\text { Squares }\end{array}$ & $\begin{array}{c}\text { Degrees of } \\
\text { freedom }\end{array}$ & $\begin{array}{c}\text { Mean of } \\
\text { squares }\end{array}$ & F-value & P-value & $\begin{array}{c}\text { Percent } \\
\text { contribution }\end{array}$ \\
\hline Reagent (R) & 460520.6 & 1 & 460520.6 & 665.154 & 0.0000 & 94.98 \\
Separation Method (SM) & 4093.9 & 1 & 4093.9 & 5.913 & 0.0229 & 0.84 \\
Number of Washes (NW) & 1318.5 & 2 & 659.3 & 0.952 & 0.3999 & 0.27 \\
$\mathrm{R}^{\star} \mathrm{SM}$ & 32.3 & 1 & 32.3 & 0.047 & 0.8308 & 0.01 \\
$\mathrm{R}^{\star} \mathrm{NW}$ & 613.3 & 2 & 306.7 & 0.443 & 0.6473 & 0.13 \\
$\mathrm{SM}^{\star} \mathrm{NW}$ & 272.5 & 2 & 136.3 & 0.197 & 0.8227 & 0.06 \\
$\mathrm{R}^{\star} \mathrm{SM}{ }^{*} \mathrm{NW}$ & 1378.9 & 2 & 689.5 & 0.996 & 0.3842 & 0.28 \\
Error & 16616.4 & 24 & 692.4 & --- & -- & 3.43 \\
Total & 484846.4 & 35 & 467131 & --- & --- & 100.00 \\
\hline
\end{tabular}

* Interaction between factors. 
This can be explained by the process of the hydrolysis of the base, described by Schneider (1984). The $\mathrm{pH}$ of the $\mathrm{NaHCO}_{3}$ solution is 8.3 at $0.1 \mathrm{~mol} / \mathrm{L}$ and the $\mathrm{pH}$ of the $\mathrm{NaOH}$ at $0.1 \mathrm{~mol}$ is 12.7 (Index, 1989). When drops of reagent are being added to a sample, a pH gradient occurs at the interface between the drops and around the solution. In this case, the stronger the base, the greater the $\mathrm{pH}$ gradient will be (Schneider, 1984). Thus, the site of the $\mathrm{NaOH}$ drop reaches a $\mathrm{pH}$ gradient of around 12.0 which led to a $30 \%$ precipitation of aluminum hydroxide.

Table 3 shows the ANOVA for the iron concentration, where it can be observed that the interaction between the factors (R, SM and SW) was more influential, its contribution being of approximately $68 \%$.

\section{Table 3}

Analysis of Variance (ANOVA) for the iron concentration.

\begin{tabular}{ccccccc}
\hline Factor & $\begin{array}{c}\text { Sum of } \\
\text { Squares }\end{array}$ & $\begin{array}{c}\text { Degrees of } \\
\text { freedom }\end{array}$ & $\begin{array}{c}\text { Mean of } \\
\text { squares }\end{array}$ & F-value & P-value & $\begin{array}{c}\text { Percent } \\
\text { contribution }\end{array}$ \\
\hline Reagent (R) & 28359 & 1 & 28359 & 1.0272 & 0.3209 & 1.02 \\
Separation Method (SM) & 163782 & 1 & 163782 & 5.9325 & 0.0227 & 5.88 \\
Number of Washes (AW) & 2002 & 2 & 1001 & 0.0363 & 0.9644 & 0.07 \\
$\mathrm{R}^{\star} \mathrm{SM}$ & 742125 & 1 & 742125 & 26.8811 & 0.0000 & 26.65 \\
$\mathrm{R}^{\star} \mathrm{NW}$ & 715481 & 2 & 357740 & 12.9580 & 0.0001 & 25.70 \\
$\mathrm{SM}^{*} \mathrm{NW}$ & 451896 & 2 & 225948 & 8.1843 & 0.0019 & 16.23 \\
$\mathrm{R}^{*} \mathrm{SM}^{\star} \mathrm{NW}$ & 18399 & 2 & 9199 & 0.3332 & 0.7199 & 0.66 \\
Error & 662584 & 24 & 27608 & --- & --- & 23.79 \\
Total & 2784628 & 35 & 1555762 & --- & --- & 100.00 \\
\hline
\end{tabular}

* Interaction between factors.

On the other hand, the optimal Fe III precipitation occurs at $\mathrm{pH}$ at 3.6, and thus the reagent does not influence the recovery of the iron. Unlike the formation of aluminum hydroxide, for which the best precipitation was at a $\mathrm{pH}$ of 7.0. With regard to the number of washes and the separation method, some loss of material which occurred in the process, led to values slightly above the confidence interval.

Figure 1 shows the behavior of the recovery of (a) iron and (b) of aluminum on using reagents, and Figure 2 shows the behavior of the recovery of (a) iron and (b) of 
aluminum on using the separation method. Aluminum is a major contaminant.

Therefore, the results from Figures 1 and 2 are very important as they show what kind of reagent must be used to recover iron and remove aluminum. $\mathrm{NaHCO}_{3}$ was more effective because it does not produce the $\mathrm{pH}$ gradient in the solution during neutralization. Thus, aluminum is not precipitated as a contaminant.

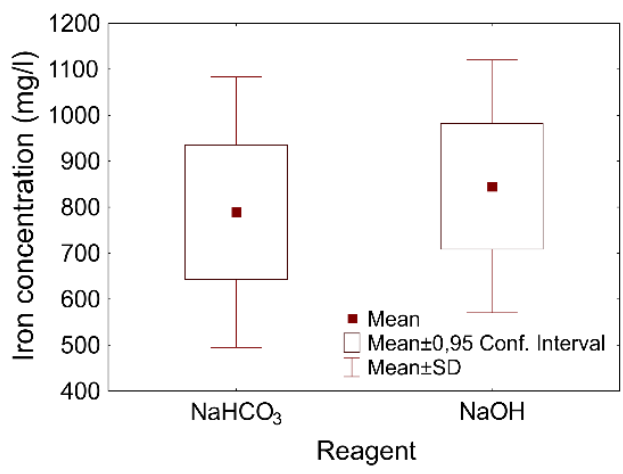

(a)

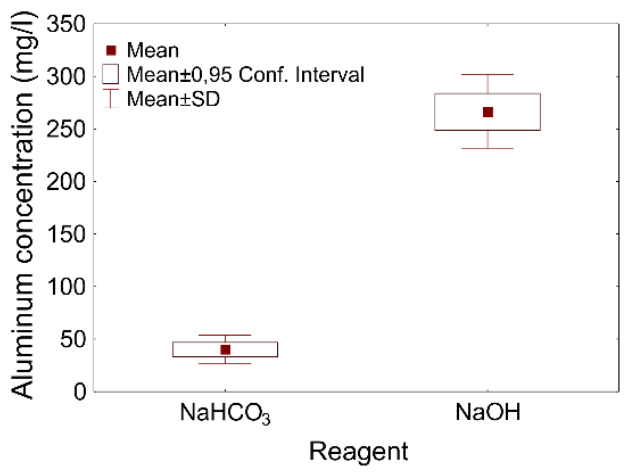

(b)

Figure 1. Influence of reagents on the recovery of (a) iron and (b) aluminum.

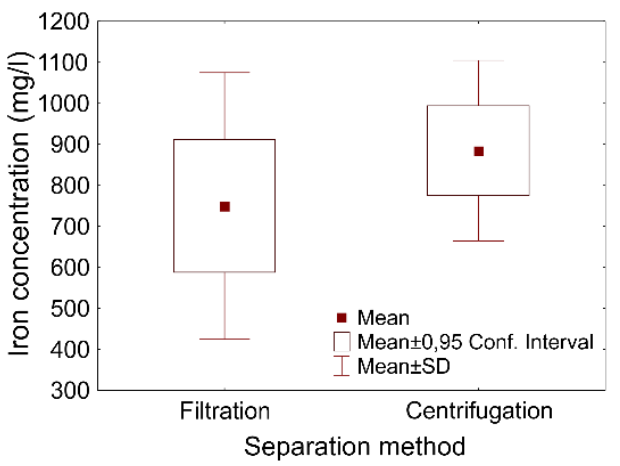

(a)

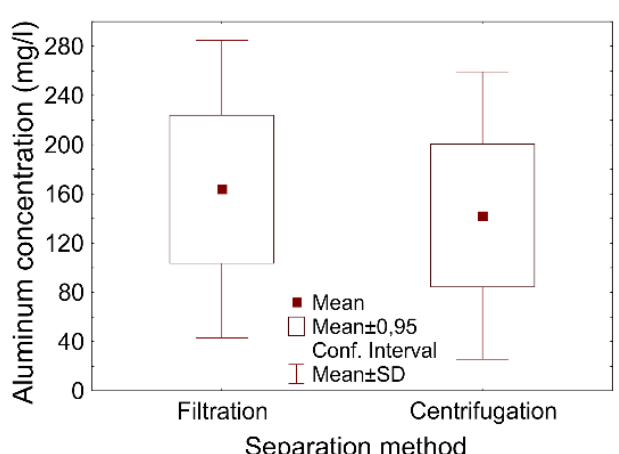

(b)

Figure 2. Influence of the separation method on the recovery of (a) iron and (b) aluminum.

Figure 3 shows the concentration of aluminum and iron based on the number of washes. Note that, on average, the concentrations remained constant irrespective of the number of washes. 


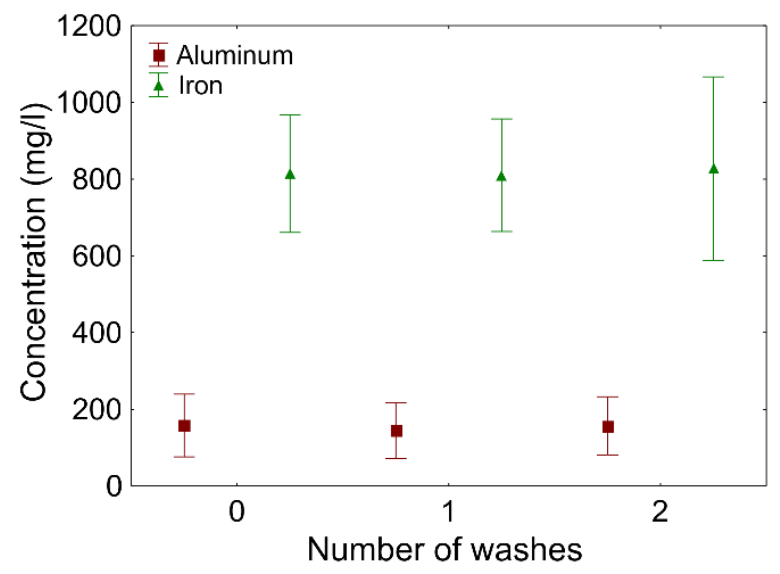

Figure 3. Concentration of aluminum and iron based on the number of washes.

The procedure for producing goethite was described by Schwertmann and Cornell (2000), Twelve samples were characterized with regard to color (Figure 4), and two samples, assay 1 and assay 6 , were chosen for the morphology and mineralogical phase, because these samples showed the greatest difference in color for the same reagent, which best removed aluminum.

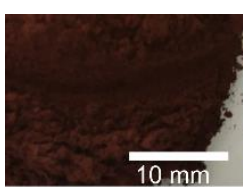

Assay 1

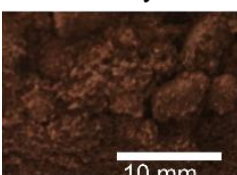

Assay 7

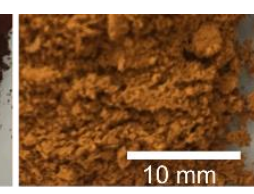

Assay 2

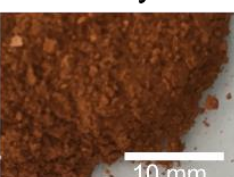

Assay 8

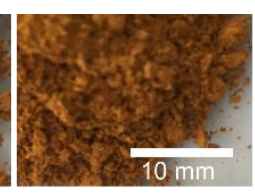

Assay 3

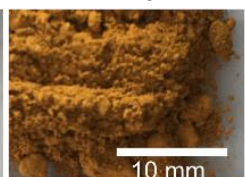

Assay 9

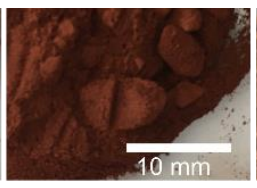

Assay 4

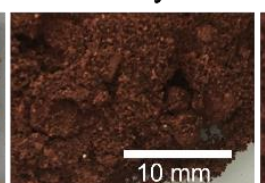

Assay 10

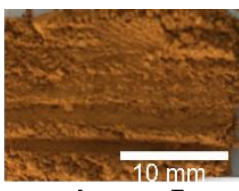

Assay 5

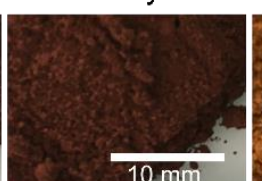

Assay 11

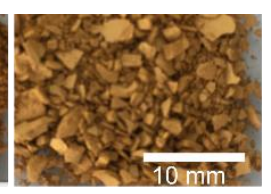

Assay 6

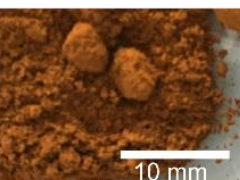

Assay 12

Figure 4. Iron oxides as pigment by the Cornell and Schwertmann (2000) route from the alkaline route.

The chemical composition was analyzed by using a Shimadzu EDX - 720 X-ray fluorescence spectrometer on two samples (assay 3 and assay 9). The results show that the precipitation with $\mathrm{NaOH}$ (assay 9) produced a solid, the composition of which was mostly $\mathrm{Fe}_{2} \mathrm{O}_{3}(81.6 \%)$ and $\mathrm{Al}_{2} \mathrm{O}_{3}(9.2 \%)$. On the other hand, when the precipitant 
reagent applied was $\mathrm{NaHCO}_{3}$ (assay 3), the $\mathrm{Fe}_{2} \mathrm{O}_{3}$ content rose to $91.7 \%$ and the aluminum content dropped to $4.1 \%$.

The colorimetric behavior of twelve samples of pigment obtained from AMD was compared with commercial goethite (Silva, 2010) by measuring reflectance in a visible range (400-700 nm) with a Minolta spectrophotometer, model 2600d. The particle size of samples was ground to less than 60 mesh to provide the shape for the colorimetric analysis, after the powder was crushed to form a circular briquette, $12.0 \mathrm{~mm} \varnothing \times 3.0$ $\mathrm{mm}$ high. Figure 5 compares the behavior of reflectance curves for 12 assays of AMD and commercial goethite.

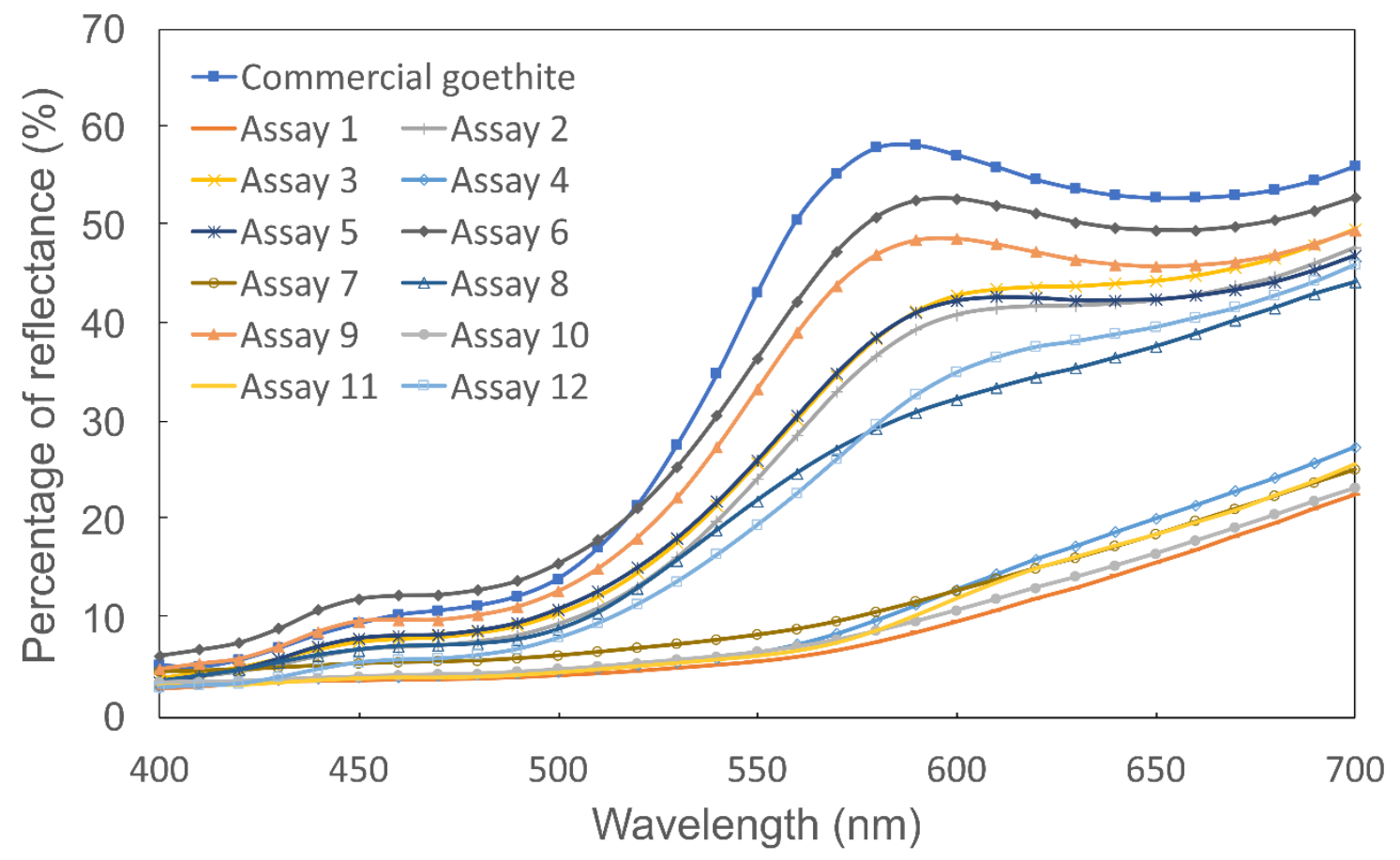

Figure 5. Percentage of Reflectance based on wavelength.

The shape of the curves demonstrates that yellow pigment must have a maximum value of reflectance between 570 and $590 \mathrm{~nm}$ (Cornell and Schwertmann, 2003). This occurred in the same way with the sample of commercial goethite and the samples produced by assays 6 and 9 . Furthermore, Cornell and Schwertmann say that the human eye sees color as a combination of three stimuli which can be described by 
corresponding spectral curves and color sensation depend of the radiant energy and sensibility of stander observer. Table 4 show the $L^{*} a^{*} b^{*}$ chromaticity color space for commercial goethite, AMD goethite obtained by Silva (2010), assay 1 and assay 6 , where can be seen that assay 6 show yellow characteristics.

\section{Table 4.}

$\mathrm{L}^{*} \mathrm{a}^{*} \mathrm{~b}^{*}$ chromaticity color space (Silva 2010).

\begin{tabular}{cccc}
\hline Samples & $\mathrm{L}^{*}$ & $\mathrm{a}^{*}$ & $\mathrm{~b}^{*}$ \\
\hline Commercial goethites & 70.7 & 7.8 & 57.1 \\
Goethite AMD & 59.2 & 8.7 & 46.8 \\
Assay 1 & 31.2 & 13.9 & 14.2 \\
Assay 6 & 66.0 & 15.6 & 44.3 \\
\hline
\end{tabular}

The shape of the colorimetric curve for assays $2,3,5,8$ and 12 shows that the reflectance values fell, mainly at the peak between 580 and $600 \mathrm{~nm}$. However, the color of the material stays similar natural "ocher".

With regard to assays $1,4,7$ and 10 , the reflectance curve is very different, as expected, because the color of the sample is not yellow. In this context, it is worth emphasizing that the samples of assays 1 and 4 were neither washed nor were they separated by centrifugation or filtration. This explains why the color produced by different procedures was similar.

The shape of the goethite particle is acicular, as described in Cornell and Schwertmann (2003). To compare AMD samples with commercial goethite, two samples - assays 1 and 6 - were chosen. The results show that assay 1 is not acicular (Figure 6(a)). It is clear that goethite was not formed in the reaction, perhaps because the conversion process may be blocked by a contaminant that adversely affects the octahedral crystallographic formation of pigment (Cornell and Schwertmann, 2003). Assay 6 has an acicular shape (Figure 6(b)), very similar to that of the commercial goethite (Figure $7(\mathrm{a})$ ) and the shape is more well-formed than the sample goethite from AMD obtained by Silva (2010) Figure 7(b). 

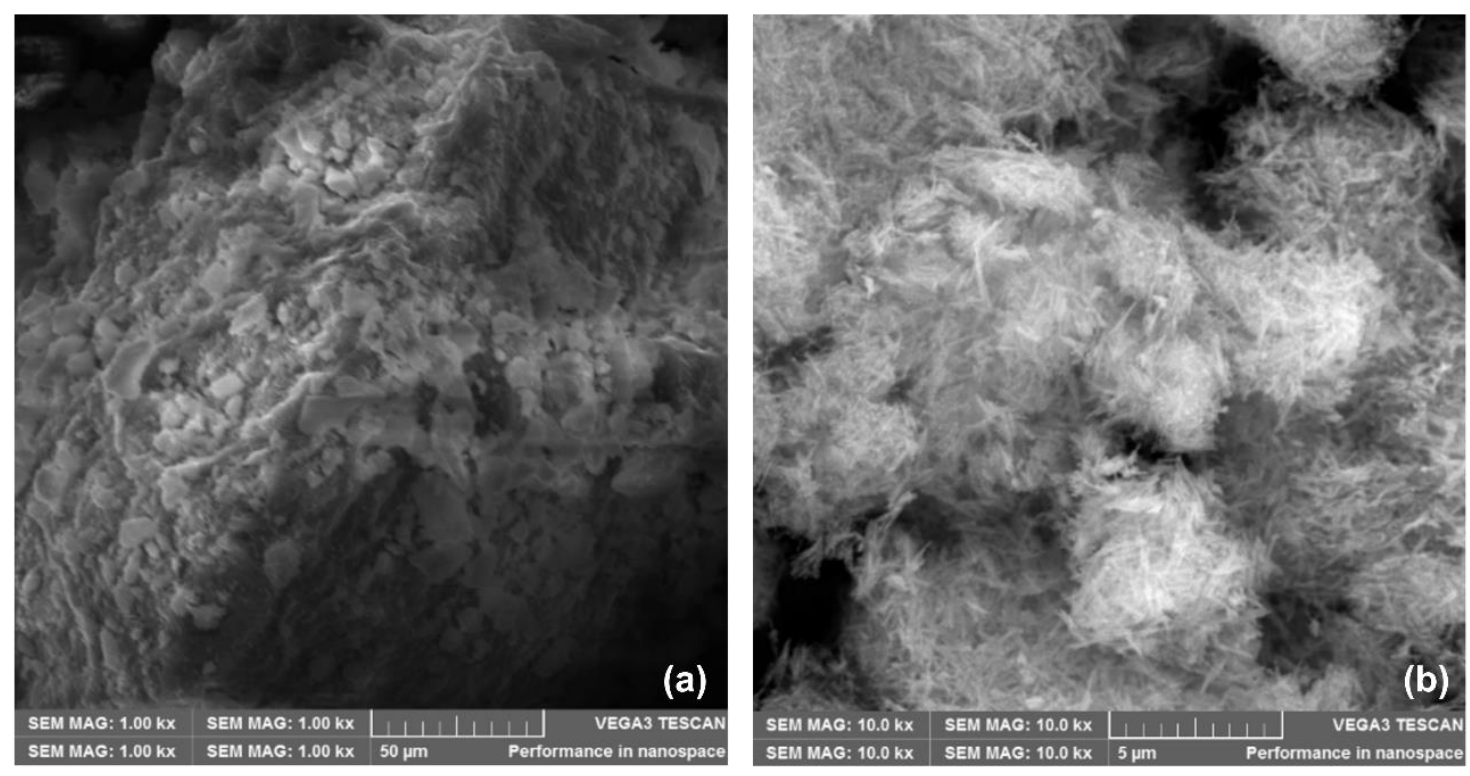

Figure 6. Morphology of pigment for (a) assay 1 and (b) assay 6 samples.
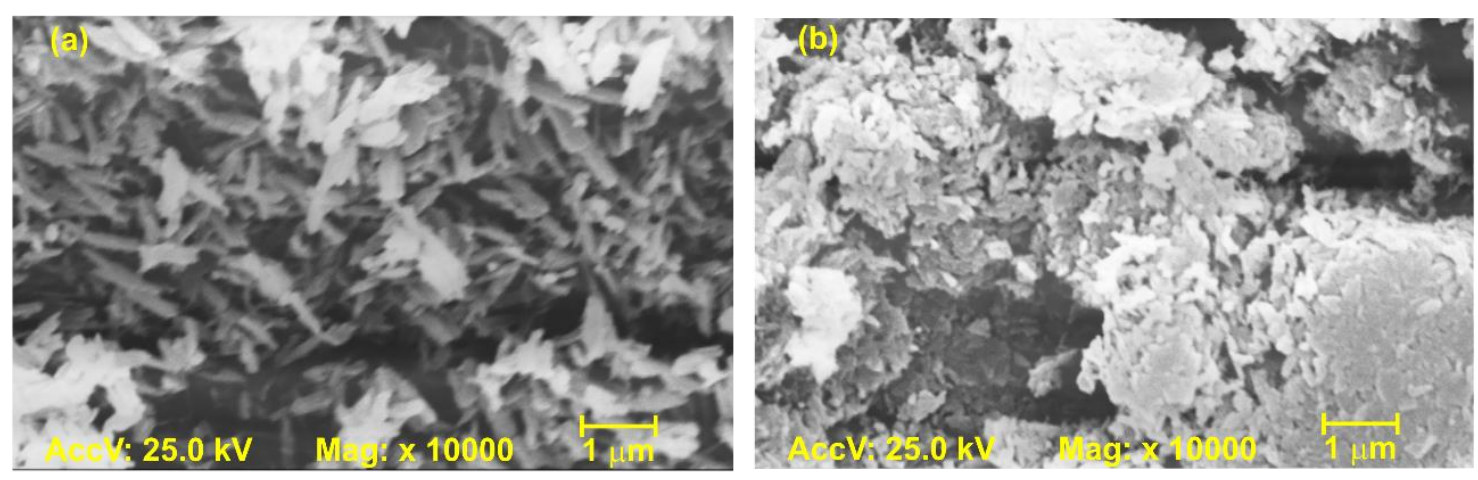

Figure 7. Morphology of (a) Commercial Goethite and (b) AMD Goethite (Silva, 2010).

The mineral phases of pigments obtained from AMD were evaluated by X-ray diffraction analysis using a Siemens Instrument, model D-5000 $(\theta-\theta)$. The results are shown in Figure 8. For assay 1 (Figure 8(a), the mineral phase detected was Hematite similarly to assay 4, 7, 10 and 11 . As to the results found for assay 6 (Figure 8(b)), only goethite was found, as well as the similar results to assay $2,3,5,8,9$ and 12 . In some cases, the peak was narrow which indicates that the crystallinity of the material was good. 

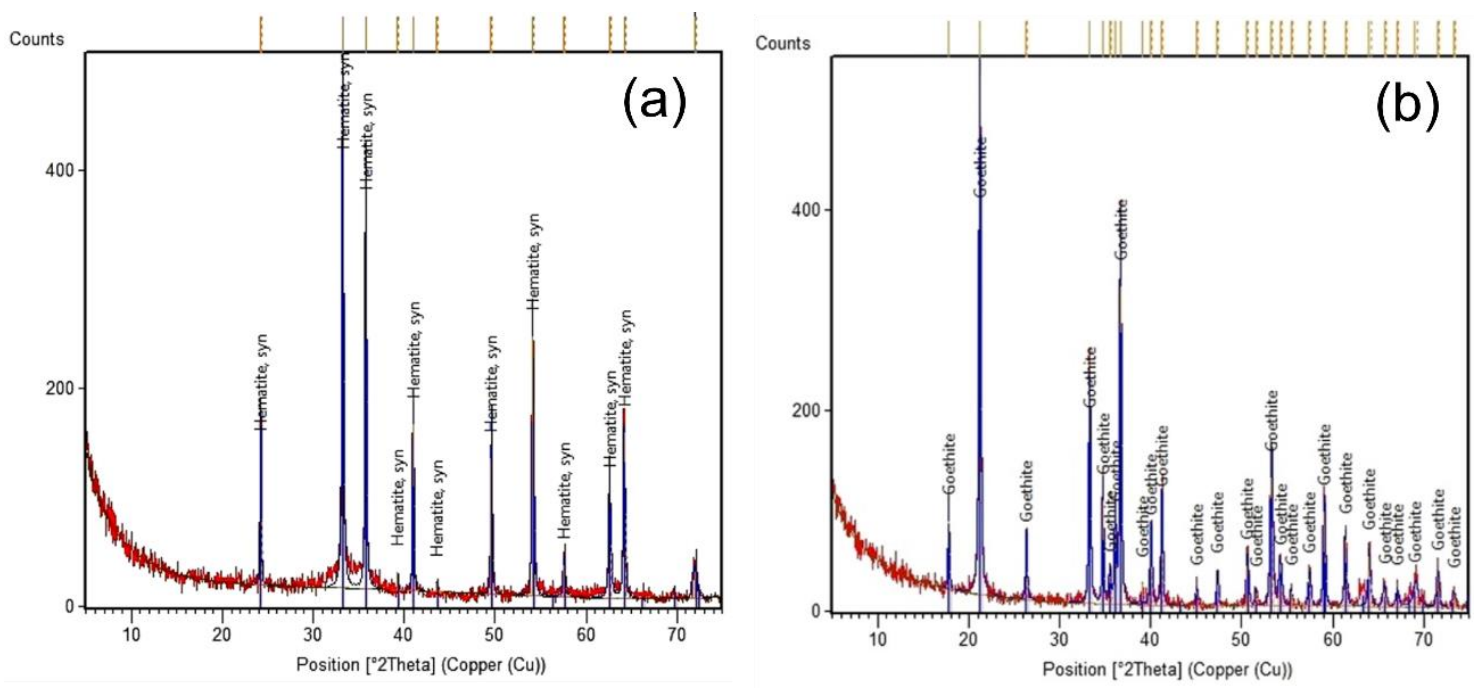

Figure 8. AMD Mineral phase for (a) assay 1 and (b) assay 6 samples.

The solubility of the aluminum is $\mathrm{pH}$ dependent. The solution reaches a minimum concentration at a pH of between 6.0 and 8.0. Thus, when sodium hydroxide is added, it leads to the formation of a $\mathrm{pH}$ gradient near the clusters of precipitated metal hydroxide. If the hydroxide flake formed is considered to be a sphere, the $\mathrm{pH}$ value decreases from the center to the edge starting near 14 and ending at $\mathrm{pH} 2.3$ which is the $\mathrm{pH}$ value of the solution (Schneider, 1984).

When the neutralization is carried out with sodium bicarbonate, this gradient is smaller, due to the weaker strength of the base. The gradient starts at around a $\mathrm{pH}$ of 7.0 and ends at a pH of 2.3. This is explained by Schneider (1984). The difference in $\mathrm{pH}$ gradient is because of the aluminum content in the precipitates obtained with $\mathrm{NaHCO}_{3}$. In addition, aluminum content adversely affects the formation of goethite crystals (Cornell and Schwertmann, 2003; Schwertmann and Cornell, 2000).

For assays 1 to 6 the iron was recovered by using $\mathrm{NaHCO}_{3}$, and for assays 7 to 12, $\mathrm{NaOH}$ was used. To produce goethite, the Cornell and Schwertmann (2003) route was used. A general view of all assay results after goethite formation in alkaline medium is shown in Figure 4. When the reagent was $\mathrm{NaHCO}_{3}, 67 \%$ of the samples 
produced yellow pigment; when the reagent was $\mathrm{NaOH}, 33 \%$ of the samples produced yellow pigment.

Elemental analysis of two samples was determined using an Energy Dispersive X-ray Fluorescence Spectrometer, model EDX-720 (Shimadzu). The results of assay 6 and assay 9 are shown in Table 5.

Table 5.

Chemical content in goethite from AMD: spectrometry results

\begin{tabular}{lcccccccccc}
\hline \multicolumn{10}{c}{ Elemental compounds } \\
\hline Samples & Fe\% & Al\% & Si\% & Mn\% & Zn\% & Cr\% & Ca\% & O\% & others & Total \\
Assay 6 & 64.2 & 2.2 & 0.1 & - & - & 0.1 & - & 30.1 & 3.3 & 100 \\
Assay 9 & 57.2 & 4.9 & 0.3 & 0.1 & 0.1 & 0.1 & 0.2 & 29.8 & 7.4 & 100 \\
\hline
\end{tabular}

The chemical analysis shows that assays 6 and 9 present some differences with regard mainly to the iron and aluminum content in the material. The only difference when preparing these samples was that the reagent added was different. The results clearly show that the strong base $(\mathrm{NaOH})$ blocks aluminum, which is a contaminant, during the precipitation process.

\section{Conclusion}

High quality goethite can be produced from AMD effluent, provided that the process for recovering iron can remove the contaminant, especially aluminum which adversely affects the growth of crystals, thereby preventing these taking an acicular form, which is characteristic of goethite pigment.

The purification results indicate that it is the kind of reagent which is mainly responsible for separating iron and aluminum during neutralization process. Due to the strength of the base, the media inside the clusters which are formed become extremely 
alkaline, which leads to metal hydroxides forming in solution near where the reagent was added.

As to the separation method of filtration/centrifugation, its influence is not great when observed in comparison with the removal of aluminum. However, this study preferred to use the filtration process because it is easier.

With regard to producing goethite from AMD as raw material, two aspects must be investigated. First, the economic feasibility with respect to the costs of the procedure must be considered. Secondly, an evaluation must be made of what reagents should be applied to convert iron from AMD into pigment. These costs should be compared with the costs of conventional treatment with disposal into the environment, without recovering material.

\section{Acknowledgments}

The authors are grateful for the financial support given by Carbonífera do Cambuí and Fundação Meridional, CNPq, and the Brazilian Coal Net for this research.

\section{References}

CONAMA, 2011. CONSELHO NACIONAL DO MEIO AMBIENTE, In Conama 430, Brasil.

Cornell, R.M., Schwertmann, U., The iron oxides: structure, properties, reactions, occurrences and uses. 2003, John Wiley \& Sons.

Eaton, A., Clesceri, L., Rice, E., Greenberg, A., Franson, M., 2005. Standard methods for the examination of water and wastewater., In Washington, DC: American Public Health Association.

Finch, J.A., Rao, S.R., Gehr, R., Riendeau, U.M., Lu, D., Acid mine drainage as a coagulant. Minerals Engineering, 1992, 5 (9), 1011-1020. 
Flores, R.G., Andersen, S.L.F., Maia, L.K.K., José, H.J., Moreira, R.d.F.P.M., Recovery of iron oxides from acid mine drainage and their application as adsorbent or catalyst. Journal of Environmental Management, 2012, 111, 53-60.

The Merck Index, Merck \& Co. Rahway, NJ, USA, 1989, 1427.

Kontopoulos, A., 1998. Acid mine drainage control. In Castro, S.H. et al. (Eds) Effluent Treatment in the Mining Industry, University of Concepción, Chile., pp. 57-118.

Marcello, R.R., Galato, S., Peterson, M., Riella, H.G., Bernardin, A.M., Inorganic pigments made from the recycling of coal mine drainage treatment sludge. Journal of Environmental Management, 2008, 88(4), 1280-1284.

Menezes, J., Silva, R., Arce, I., Schneider, I., Production of a poly-ferric sulfate chemical coagulant by selective precipitation of iron from acidic coal mine drainage. Mine Water and the Environment, 2009, 28(4), 311.

Menezes, J., Silva, R., Arce, I., Schneider, I., Production of a poly-alumino-iron sulfate coagulant by chemical precipitation of a coal mining acid drainage. Minerals Engineering, 2010, 23(3), 249-251.

Nordstrom, D.K., Bowell, R.J., Campbell, K.M., Alpers, C.N., 2017. Challenges in recovering resources from acid mine drainage, In Mine Water and Circular Economy. Proceedings of the 2017 International Mine Water Association Conference held, p. 30.

Schneider, W., Hydrolysis of iron (III)...chaotic olation versus nucleation. Comments on Inorganic Chemistry, 1984, 3(4), 205-223.

Schwertmann, U., Cornell, R.M., Iron oxides in the laboratory. Preparation and Characterization, 2nd, Completely Revised and Enlarged Edition 2000, 4-18. Wiley Schwertmann, U., Murad, E., Effect of $\mathrm{pH}$ on the formation of goethite and hematite from ferrihydrite. Clays and Clay Minerals, 1983, 31(4), 277-284. 
Schwertmann, U., Stanjek, H., Becher, H.-H., Long-term in vitro transformation of 2-line ferrihydrite to goethite/hematite at 4, 10, 15 and 25 C. Clay Minerals, 2004, 39(4), 433438.

Silva, R. de A., Recuperação hidrometalúrgica de metais da drenagem ácida de minas por precipitação seletiva. 2010. Ph. D. Thesis, UFRGS, Porto Alegre, Brazil (in Portuguese).

Silva, R. de A., Castro, C.D., Vigânico, E.M., Petter, C.O., Schneider, I.A.H., Selective precipitation/UV production of magnetite particles obtained from the iron recovered from acid mine drainage. Minerals Engineering, 2012, 29, 22-27.

Silva, R. de A., Menezes, J.C.S. dos S., Lopes, F.A., Kirchheim, A.P., Schneider, I.A.H., Synthesis of a goethite pigment by selective precipitation of iron from acidic coal mine drainage. Mine Water and the Environment, 2017, 36(3), 386-392.

Silveira, A.N.da, Silva, R., Rubio, J., Treatment of Acid Mine Drainage (AMD) in South Brazil: Comparative active processes and water reuse. International Journal of Mineral Processing, 2009, 93(2), 103-109.

Skousen, J., Rose, A., Geidel, G., Foreman, J., Evans, R., Hellier, W., Handbook of technologies for avoidance and remediation of acid mine drainage. National Mine Land Reclamation Center, Morgantown, 1998, 131 pp.

Skousen, J.G., Ziemkiewicz, P.F., Acid mine drainage control and treatment. National Mine Land Reclamation Publication Morgantown: West Virginia University, 1995, 254 pp.

Stumm, W., Morgan, J.J., Aquatic chemistry: chemical equilibria and rates in natural waters. 2012, John Wiley \& Sons.

Wei, X., Viadero Jr, R.C., Buzby, K.M., Recovery of iron and aluminum from acid mine drainage by selective precipitation. Environmental Engineering Science, 2005, 22(6), 745-755. 